\title{
CORREÇÃO DO RESULTADO MENSAL
}

\author{
Autores: Ariovaldo dos Santos \\ Geraldo Barbieri \\ Mestres e Doutorandos pelo Departamento de Contabilidade e Atuaria da FEA/USP \\ Professores Assistentes do Departamento de Contabilidade e Atuaria da FEA/USP.
}

(Este artigo será enviado para publicação no Boletim IOB)

\section{Introdução}

A correção monetária do lucro do próprio exercício é um assunto que já causou muita polemica e que agora, com a edição da Lei n요.383 de 30.12.91, vem à tona novamente.

O capitulo IV da referida Lei versa sobre o Imposto de Renda das pessoas jurídicas.

"Artigo 38 - A partir do mês de 1992, o imposto de renda das pessoas jurídicas será devido mensalmente, à medida que os lucros forem auferidos".

Parágrafo 1ํ- Para efeito do disposto neste artigo, as pessoas jurídicas deverão apurar, mensalmente a base de calculo do imposto devido.

Parágrafo 9ำ- Os resultados apurados em cada mês serão corrigidos monetariamente (Lei ํㅜ 8.200 de 1991) “.

No artigo 39 da Lei no 8.383 encontramos algumas opções para o pagamento do imposto de renda devido, mas o parágrafo 3 o do artigo 39 determina que o imposto apurado nos balanços ou balancetes seja convertido em quantidade de UFIR diária pelo valor desta no último dia do mês a que se referir e, conforme o parágrafo 6 do mesmo artigo, o imposto devido de cada mês, após as deduções possíveis poderá ser pago até o último dia do mês a que se referir e, conforme o parágrafo 6ำ do mesmo artigo, o imposto devido em cada mês, após as deduções possíveis poderá ser pago até o último dia útil do mês subseqüente, desde que atualizado.

Ainda de acordo com o artigo 39 , parágrafos $7^{\circ}$ e $8^{\circ}$, o prejuízo apurado na demonstração do lucro real em um mês poderá ser compensado com o lucro real dos meses subseqüentes e, para efeito desta compensação, o prejuízo será corrigido monetariamente com base na variação acumulada da UFIR diária.

A fim de esclarecer melhor o assunto vamos trabalhar com um exemplo simples, mostrando também as demonstrações de acordo com a metodologia da Correção Integral (Legislação CVM - Comissão de Valores Mobiliários).

BALANÇOS 


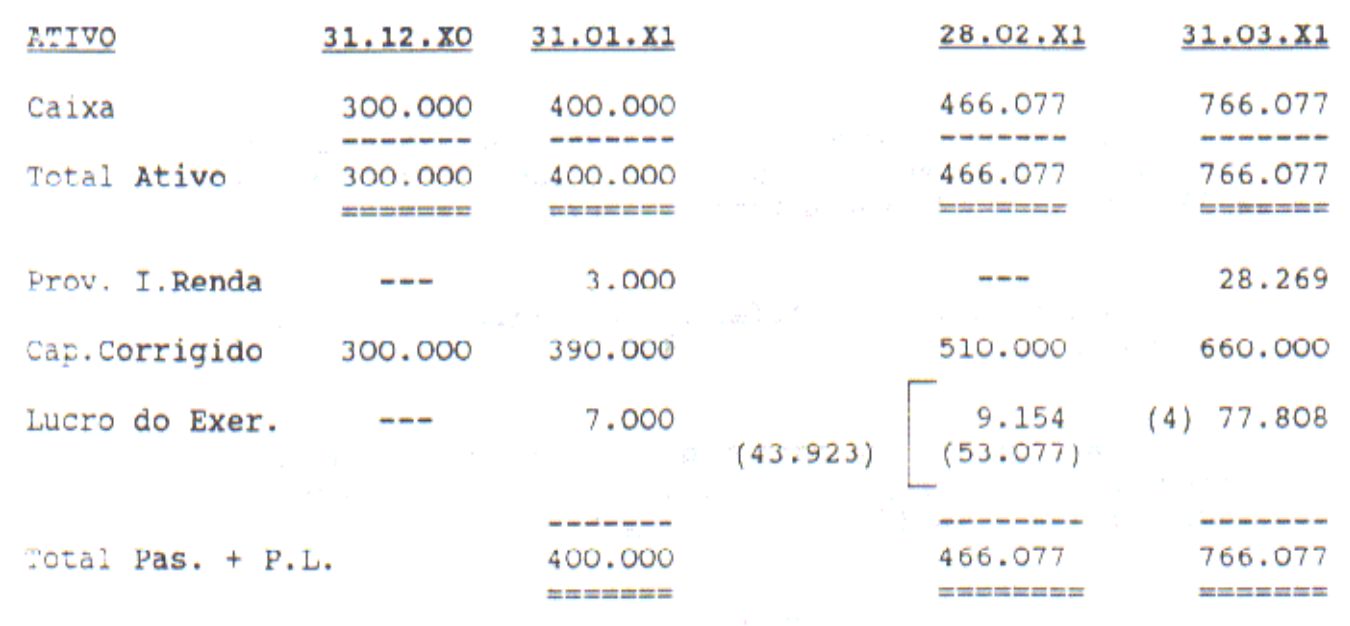

Demonstrações de resultados

\begin{tabular}{c} 
Janeiro X1 \\
500.000 \\
$(100.000)$ \\
\hline 100.000 \\
--- \\
$(90.000)$ \\
$-9 .---$ \\
10.000 \\
$(3.000)$ \\
----- \\
7.000 \\
$====$
\end{tabular}

Fevereiro $\mathrm{x}, 1$

550.000

(480.000)

$------$

70.000

(923)

(122.154)

-

(53.077)

$---$

$----$

$(53.077)$

$=== \pm==$
Março X1

800.000

(500.000)

300.000

$--$

(137.081)

-----

162.919

(28.269)

$-0---$

134.650

$== \pm===$

(OBS: Todas as receitas e custos dos serviços foram a vista)

\begin{tabular}{|c|c|c|c|}
\hline UFIR's & & & \\
\hline $31.12 . \mathrm{xO}$ & $=$ & $\$$ & 100,00 \\
\hline Médio Janeiro & $=$ & $\$$ & 114,00 \\
\hline $31.01 . \times 1$ & $=$ & $\$$ & 130,00 \\
\hline Médio Fevereiro & $=$ & $\$$ & 148,00 \\
\hline $28.02 . \times 1$ & $=$ & $\$$ & 170,00 \\
\hline Médio Março & $=$ & $\$$ & 195,00 \\
\hline $31.03 . \times 1$ & $=$ & $\$$ & 220,00 \\
\hline
\end{tabular}

(1) Janeiro

Capital Corrigido $=\$ 300.000 \times 130,00=\$ 390.000$

$$
\begin{array}{r}
(----) \\
100,00
\end{array}
$$

Valor da Correção $=\$ 390.000-\$ 300.000=\$ 90.000$ 
(2) Fevereiro

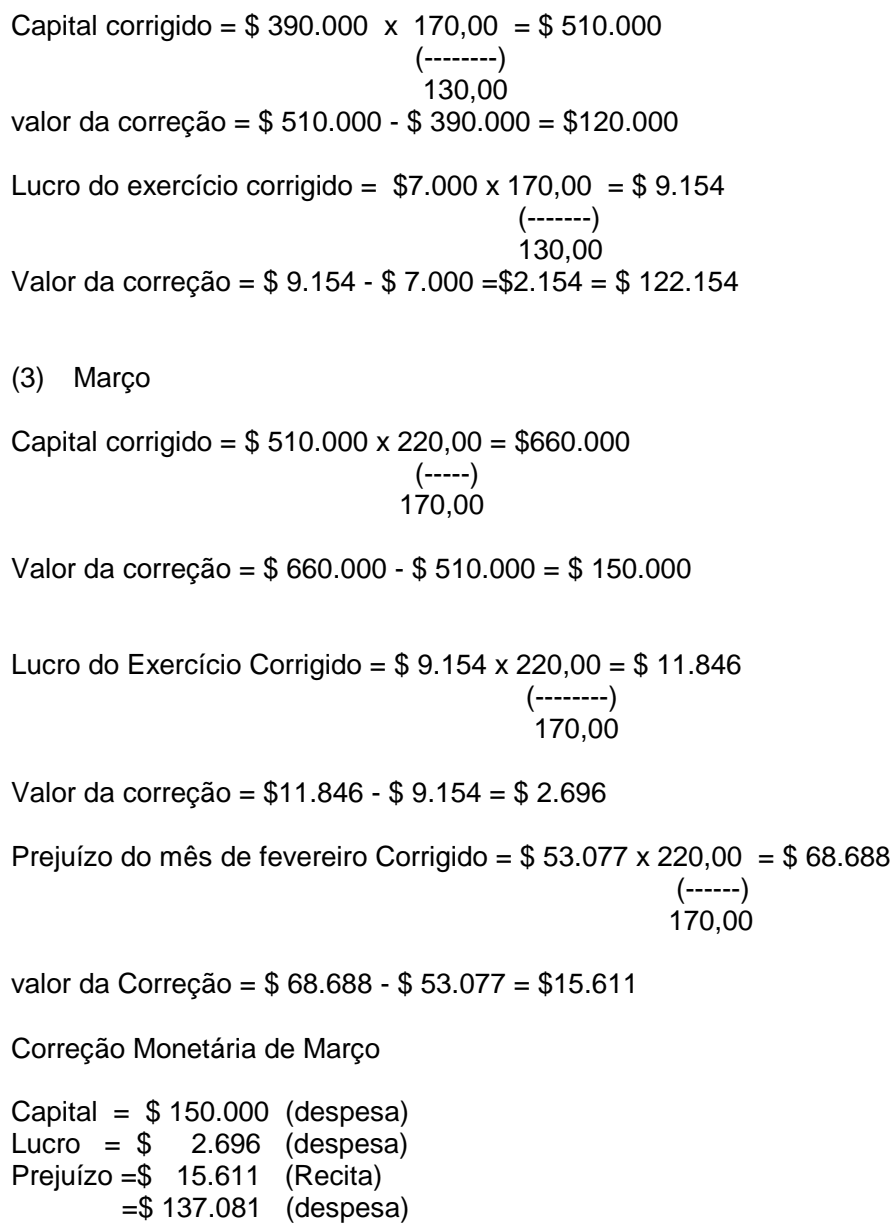

Fizemos a correção monetária do lucro e do prejuízo separadamente para efeitos didáticos; poderíamos faze-la de uma só vez e chegaríamos ao mesmo numero, ou seja,

$(\$ 9.154-\$ 53.077) \times 220,00-1)=\$ 12.919 R=(\$ 15.611 R-\$ 2.692 D)$

$$
\left(\frac{(}{170,00}\right)
$$

2) Provisão para Imposto de Renda (supondo-se alíquota de $30 \%$ ): janeiro $=\$ 10.000 \times 0,30=\$ 3.000$, que foram pagos em 28.2 corrigidos pela UFIR.

Março = Lucro antes de compensar o prejuízo $=\$ 162.919$

Prejuízo corrigido

$\$(68.688)$

Lucro Tributável

$\$ 94.231$

$\times 0,30$

Provisão para Imposto de Renda

$=\overline{28.269}$

3) Despesas de Variação Monetária do Imposto de Renda de Fevereiro $\$ 3.000 \times 170.000-=\$ 923$

$$
\text { (-----) }
$$

4) Lucro do exercício acumulado até março:
Lucro de janeiro corrigido até março
$=\$ 11.846$
Prejuízo de fevereiro corrigido até março
$=\left(\begin{array}{ll}\$ & 68.688\end{array}\right)$ 
Lucro de março

$=(\$ 134.650)$

$\overline{\$ 77.808}$

Veja que agora com o Lucro Acumulado do Exercício não é a simples soma dos resultados de cada um dos meses e sim a soma destes resultados corrigidos para a moeda de 31.03.x1.

Outra dúvida que temos observado é com respeito á compensação do prejuízo de um mês com os lucros dos meses seguintes, visto que aparentemente será compensado um prejuízo maior, pois esta compensação será feita utilizando o valor do prejuízo corrigido. Isto é ilusão pois, voltando ao exemplo, temse:

Em fevereiro a empresa do exemplo gerou um prejuízo tributável de \$53.077 que em moeda de 31.03.x1 é $=\$ 53.077 \times(220: 170)=\$ 68.688$; portanto esta sendo compensado um valor maior de 15.611 (\$68.688 53.077), mas se observarmos a conta de correção monetária do mês de março veremos que foram computadas como receitas de correção monetária do prejuízo exatamente esse mesmo valor.

Como fica isso com a Correção Integral?

A comissão de Valores mobiliários, através das instruções no146/91 e 167/91, determina que, a opção da empresa, as companhias abertas poderão, deste que consistentemente ao longo de cada exercício, utilizar para registro de suas transações as seguintes alternativas:

a) Variação mensal da UFIR

b) A UFIR diária para todas as transações ocorridas no período;

c) Variação monetária da UFIR no período;

d) Critério misto, sendo:

1) A UFIR diária para as transações que envolvam as contas do ativo permanente e patrimônio liquido e, se for o caso, dos demais itens não monetários;

2) Variação média da UFIR para as demais transações, inclusive para registro das quotas de depreciação, amortização e exaustão.

Usaremos para o exemplo a alternativa (d) item (2), visto que não houve alteração nas contas consideradas não monetária (Patrimônio Liquido) a não ser pelos resultados obtidos

Transformação em UFIR's

$\begin{array}{lcccc}\text { Receitas } & \$ & \text { UFIR (Média) } & & \text { no de UFIR's } \\ \text { Janeiro } & 500.000: & \$ 114,00 & = & 4.385,9649 \\ \text { Fevereiro } & 550.000: & \$ 148,00 & = & 3.716,2162 \\ \text { Março } & 800.000: & \$ 195,00 & = & 4.102,5641 \\ & & & & \\ \text { Total } & 1.850 .000 & & & 12.204,7452\end{array}$

Custos dos Servidores

\begin{tabular}{|c|c|c|c|}
\hline Janeiro & 400.000 & $\$ 114,00$ & $=3.508,7719$ \\
\hline Fevereiro & 480.000: & $\$ 148,00$ & $3.243,2432$ \\
\hline Março & 500.000: & $\$ 195,00$ & $2.564,1026$ \\
\hline Total & 1.380 .000 & & $9.316,1177$ \\
\hline
\end{tabular}

GANHOS/PERDAS NOS ITENS MONETARIOS QUE NÃO GERAM RECEITAS OU DESPESAS FINANCEIRAS

Caderno de Estudos n4, São Paulo, FIPECAFI - Março/1992 


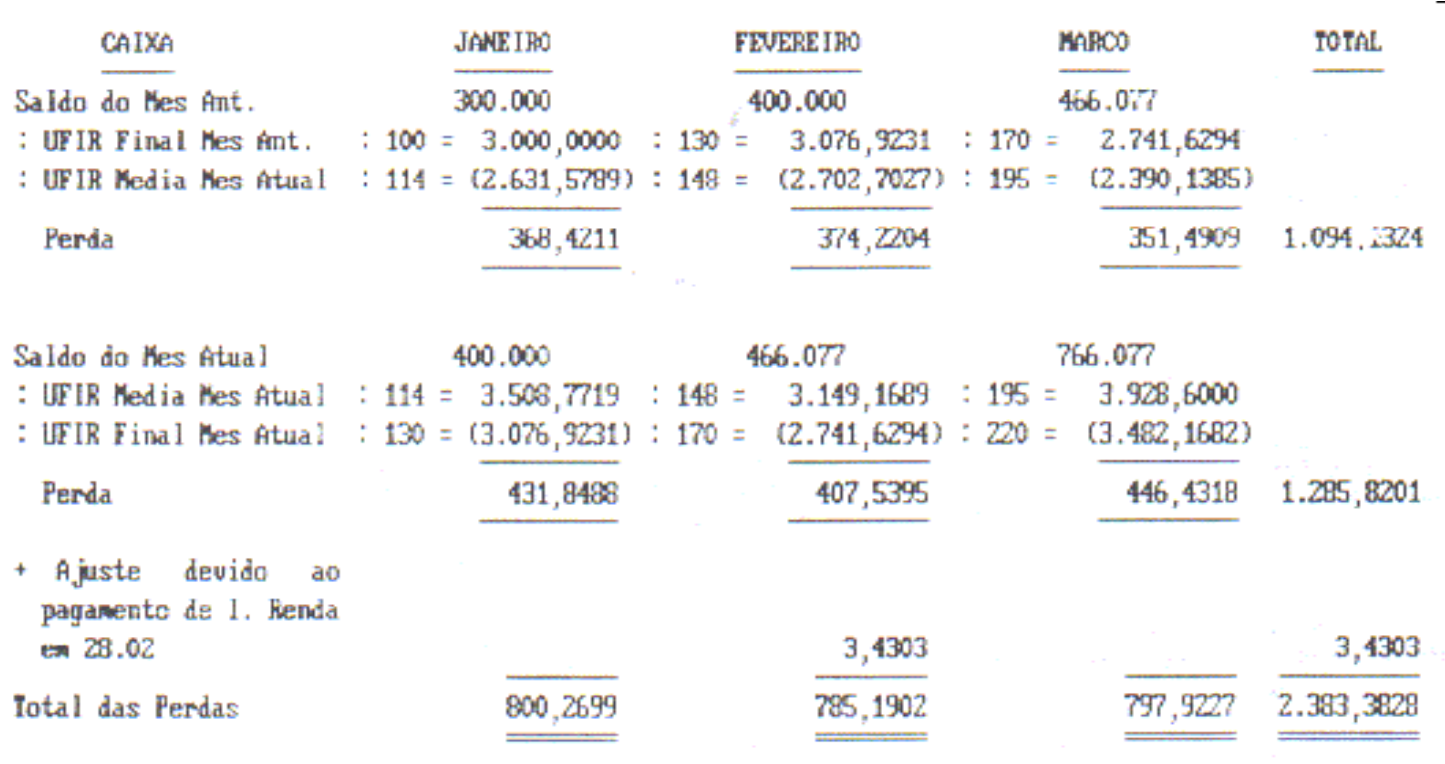

Calculo da provisão para Imposto de Renda

A provisão para o imposto de renda é um valor que já esta em moeda de final do mês, portanto, basta dividir o valor provisionada pela UFIR do final do mês, ou seja:

Provisão para imposto de renda de janeiro $=\$ 3.000: \$ 130=23,0769$.

Como as receitas e despesas foram divida pela UFIR média, se a empresa quiser também calcular a provisão para o Imposto de Renda pela UFIR média terá que calcular o ganho sobre este valor do seguinte modo:

Provisão do mês dividida pela UFIR média do mês $3.000: 114=26,3158$, menos o ganho gerado

Ganho na Provisão para o Imposto de Renda

Saldo do mês anterior : UFIR do final do mês anterior $0: 100=0$

Saldo do mês anterior: UFIR média do mês atual

$0: 114=0$

Saldo

Saldo do mês atual : UFIR média do mês atual Saldo do mês atual: UFIR do final do mês atual

Ganho

Total dos ganhos

$$
\begin{array}{r}
=3.000: 114=26,3158 \\
=3.000: 130=23,0769 \\
-\begin{array}{r}
- \\
3,2389
\end{array} \\
----2389
\end{array}
$$

Subtraindo da provisão para imposto de rendo os ganhos proporcionados por esta provisão teremos 26,3158 - 3,0769, que é exatamente o valor calculado dividindo os $\$ 3.000$ de provisão pela UFIR de $31.01=\$ 3.000: 3.000: \$ 130=23,0769$, que é exatamente o valor calculado dividindo os 3.000 de provisão pela UFIR de $31.01=\$ 3.000: \$ 130=23,0769$

Para o mês de março vamos simplesmente dividir a provisão de março pela UFIR de $31.03=\$ 28.269: \$ 220=128,4955$ UFIR's.

Como os 3.000 de imposto provisionados em janeiro serão pagos em 28.02, corrigidos, aquele valor gerou uma despesa de variação monetária de $\$ 923$, mais ao utilizarmos a metodologia da correção integral verificamos que esta despesa simplesmente não existe, pois a provisão para o imposto de renda é um passivo monetário e ela irá gerar um ganho sobre os $\$ 3.000$ de valor igual às despesas de variação monetária, uma vez que o imposto de renda foi corrigido pela variação da UFIR, mas a provisão paRA Imposto de Renda ficou exposta à mesma inflação, ou seja: 
Despesas de Variação Monetária

Despesa de Variação Monetária 923

Saldo Prov.l. Renda mês anterior 3.000

UFIR Final do mês anterior

UFIR média do mês atual

Saldo Prov.l. Renda mês atual 3.923

UFIR médio do mês atual

UFIR Final do mês atual

$$
\begin{aligned}
& : 148=6,2365 \\
& : 130=23,0769 \\
& : 148=(20,2703) \quad(2,8066) \\
& : 148=26,5068 \\
& : 170=(23,070765)
\end{aligned}
$$

Despesas de Variação Monetária

Se Olharmos o balanço de 28.02.X +1 não encontraremos o saldo de provisão para imposto de renda de $\$ 3.923$, mas é fácil entender que se o imposto de renda foi pago em 28.02. $\mathrm{X}+1$, este valor foi baixado nesta data e portanto gerou ganho até este dia.

Ao considerarmos este ganho, precisamos fazer também um ajuste nas perdas de caixa, pois a conta caixa foi diminuída de $\$ 3.923$ somente no dia 28.02; então, até o dia 28.02 devemos calcular a perda adicional no caixa sobre os $\$ 3.923$ e é por este motivo que temos no mês de fevereiro um ajuste das perdas no caixa de 3,4303 UFIR's.

\section{Comparação das Demonstrações de Resultados}

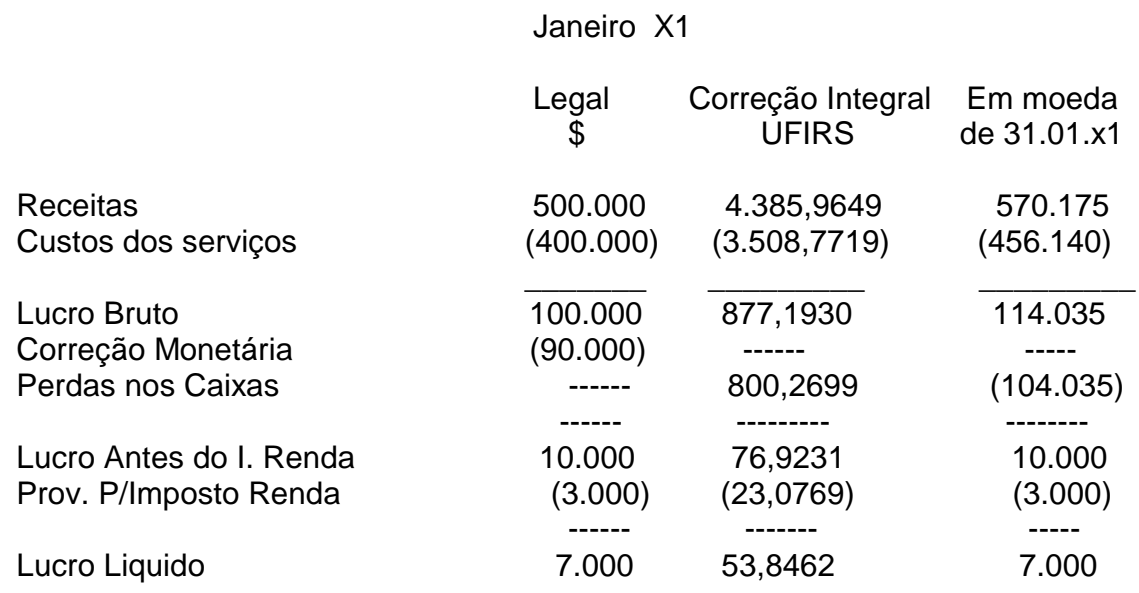

Significado da Conta de Correção Monetária

Correção das Receitas

Correção dos Custos

Perdas no Caixa

Valor da Correção Monetária

$\begin{array}{rlrl}570.175-500.000 & = & 70.175 \mathrm{R} \\ 456.140-400.000 & = & 56.140 \mathrm{D} \\ & = & - \\ -\cdot-\cdot--- & 90.000 \mathrm{D}\end{array}$

Comprando as Demonstrações de Resultados

Fevereiro X1 


\begin{tabular}{|c|c|c|c|c|c|}
\hline & \multirow{2}{*}{$\begin{array}{l}\text { Legal } \\
\qquad \hat{s}\end{array}$} & \multicolumn{2}{|c|}{ Correcao Integral } & \multicolumn{2}{|c|}{$\begin{array}{l}\text { Correcan Integral } \\
\text { Acumulados ate Fevereiro }\end{array}$} \\
\hline & & UFIR's & $\$$ & UfIR's & $\$$ \\
\hline $\begin{array}{l}\text { Receitas } \\
\text { Custos dos Servicos }\end{array}$ & $\begin{array}{c}550.000 \\
(490.000)\end{array}$ & $\begin{array}{c}3.716,2162 \\
(3.243,2432)\end{array}$ & $\begin{array}{l}631.756 \\
\text { (551.351) }\end{array}$ & $\begin{array}{c}8.102,1811 \\
(6.752,0151)\end{array}$ & $\begin{array}{c}1,377.371 \\
(1,147.842)\end{array}$ \\
\hline $\begin{array}{l}\text { Lucro Bruto } \\
\text { Despaesas U. Kon. 1.R. } \\
\text { Correcao Monetaria }\end{array}$ & $\begin{array}{r}70.000 \\
(923) \\
(122.154)\end{array}$ & $\begin{array}{c}472,9730 \\
- \\
-\end{array}$ & $\begin{array}{l}80.405 \\
- \\
-\end{array}$ & $1.350,1666$ & 229.528 \\
\hline Perdas no Caixa & - & $(725,1902)$ & $(133.482)$ & $(1.585,4601)$ & $(269.528)$ \\
\hline $\begin{array}{l}\text { Lucro fintes do I. Renda } \\
\text { Prov. p inposto Renda }\end{array}$ & $\begin{array}{c}(53.077) \\
-\end{array}$ & $\frac{(312,2172)}{-}$ & $\begin{array}{c}(53.077) \\
-\end{array}$ & $\begin{array}{r}(235,2935) \\
(23,0769)\end{array}$ & $\begin{array}{r}(40.000) \\
(3.923)\end{array}$ \\
\hline Lucro Liquido & (53.077) & $\underline{(312,2172)}$ & $\stackrel{(53.07)}{=}$ & $\stackrel{(258,3704)}{=}$ & $\stackrel{(43.923)}{=}$ \\
\hline
\end{tabular}

Significado da Conta de Correção Monetária

$\begin{array}{lcccc}\text { Correção das Receitas } & (631.756-550.000) & = & 81.756 & R \\ \text { Correção dos Custos } & (551.351-480.000) & =71.351 & \text { D } \\ \text { Perdas no Caixa } & & 133.482 & \text { D } \\ \text { Ganho na Prov. I. Renda } & & 923 & \text { R } \\ & & & 122.154 & \text { D }\end{array}$

É de se notar que com a introdução na conta de correção monetária da correção do lucro do próprio exercício, desde que não se corrija outras contas não monetárias e que não se faça ajustes a valor presente, o resultado mensal, legal e integral serão sempre os mesmos.

Agora o resultado legal do mês esta correto, o que não aconteceria antes, pois não incluindo a correção do resultado do exercício na conta de correção monetária, este valor estava errado e provocava um erro no resultado do mês seguinte, pois este continha a correção dos resultados dos meses anteriores.

Para confirmar o que estamos dizendo, vamos demonstrar que se não fosse incluída na conta de correção monetária do lucro de janeiro, o resultado de fevereiro seria somente a correção do capital corrigido = \$ $390.000 \times 170,00=120.000$

$(------1)$

130,00

de despesa e o que esta sendo considerado na demonstração é $\$ 122.154$; se fossem considerados somente os $\$ 120.000$ o resultado de fevereiro seria:

Lucro após despesa financeira $\$ 70.000-\$ 923=\$ 69.077$

Saldo da correção

$(\$ 120.000)$

Resultado Liquido

(50.923)

E não (\$53.077); portanto seria maior em \$2.154, o resultado de fevereiro estaria aumentando exatamente do valor da correção monetária do lucro de janeiro.

Devemos observar também os resultados acumulados integral e legal neste exemplo são iguais e somam (\$ 43.923) e que, para chegar-se a este valor não podemos simplesmente somar os $\$ 7.000$ de lucro de janeiro com os $\$ 53.077$ de prejuízo de fevereiro; o certo é $\$ 7.000$ corrigidos para moeda de fevereiro (7.000 x 170 : $130=\$ 9.154)$ menos o prejuízo de fevereiro $\$ 53.077$, chegando-se aos $\$ 43.923$ conforme evidenciado anteriormente no balanço de 28.02.x1. Demonstração do Resultado
Março

Caderno de Estudos nº, São Paulo, FIPECAFI - Março/1992 


\begin{tabular}{|c|c|c|c|c|c|}
\hline & \multirow{2}{*}{$\begin{array}{c}\text { Legal } \\
\$\end{array}$} & \multicolumn{2}{|c|}{ Correcao Integral } & \multicolumn{2}{|c|}{$\begin{array}{l}\text { Correcao integral } \\
\text { Acumulado ate Karco }\end{array}$} \\
\hline & & UrIR's & $\$$ & UFIR's & $\hat{s}$ \\
\hline Receitas & 800.000 & $4.102,5641$ & 902.565 & $12.204,7452$ & $2,605.044$ \\
\hline Custos dos Servicos & $(500.000)$ & $(2.564,1026)$ & (564.103) & $(9.316,1177)$ & $(2,049.546)$ \\
\hline Lacro Eruto & 300.000 & $1.538,4615$ & 338.462 & $2.898,6275$ & 635.498 \\
\hline Correcao Honetaria & $(137.081)$ & - & - & - & - \\
\hline Perdas no Caixa & - & $(797,9227)$ & $(175.543)$ & $(2.383,3828)$ & $(524.344)$ \\
\hline Lucro Antes do I. Renda & 162.919 & 740,5388 & (162.919) & 505,2447 & 111.154 \\
\hline Prov. p/Inposto henda & (28.269) & $(128,4955)$ & $(28.269)$ & $(151,5724)$ & (33.346) \\
\hline Lucro Liquido & 134.650 & 612,0433 & 134.650 & 357,6723 & 77.208 \\
\hline
\end{tabular}

Significado da Conta de Correção Monetária

$\begin{array}{lrrr}\text { Correção das Receitas } & (902.565-800.000) & =102.565 \mathrm{R} \\ \text { Correção dos Custos } & (564.103-500.000) & =64.565 \mathrm{D} \\ \text { Perdas no Caixa } & & =175.543 \mathrm{D} \\ & & -137.081 \mathrm{D}\end{array}$

Mas uma vez verificamos que os resultados de março, nos métodos legais e integrais, São iguais, confirmando que o resultado legal agora é verdadeiro. Antes da inclusão da correção monetária do resultado do próprio exercício havia sempre uma super avaliação nos resultados mensais. Lembramos mais uma vez que, para chegarmos ao resultado acumulado de $\$ 77,808$, não podemos simplesmente somar os resultados mensais. Devemos corrigi-los para a moeda de março, ou seja:

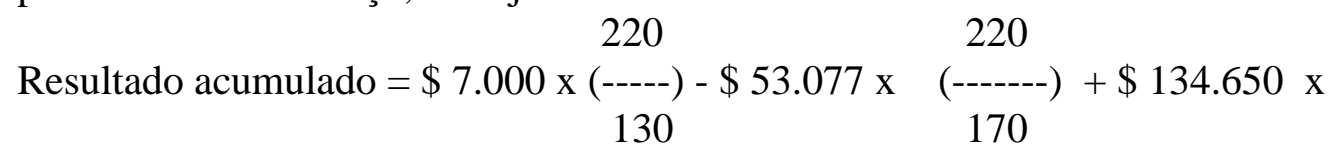

$(-----)=77.808$, que é exatamente o valor do lucro acumulado que encontramos 220 no balanço de 31.03.X+1. 
Lembramos também que para chegarmos ao imposto de renda acumulado pelo método da correção monetária legal, temos que atualizar os \$ 3.000 até março e só depois soma-lo ao imposto de março, ou seja: $\$ 3.000 \times(220: 130)+\$ 28.269=\$ 33.346$.

Devemos observar ainda que a Lei 8383 de 30/12/91, em seu artigo 43 determina que as pessoas jurídicas embora tenham calculado e pago o imposto de renda com base em balanços e balancetes mensais, deverão apresentar em cada ano, declaração de ajuste anual, consolidando os resultados mensais.

\section{CADERNO DE ESTUDOS}

FIPECAFI/FEA-USP

\section{CORREÇÃO DO RESULTADO MENSAL}

Autores: Ariovaldo dos Santos

Geraldo Barbieri

Mestres e Doutorandos pelo Departamento de Contabilidade e Atuaria da FEA/USP

Professores Assistentes do Departamento de Contabilidade E Atuaria da FEA/USP

(Este artigo será enviado para publicação no Boletim IOB).

Por derradeiro, sabemos que, segundo o Prof. Sergio de Iudicibus (Teoria da Contabilidade, $1^{\text {a }}$ edição, São Paulo: Atlas, 1981, p.122), pode-se...reconhecer certas exigibilidades contingentes em situações que, pelo vulto do cometimento que podem acarretar para a entidade (mesmo que os eventos caracterizem a exigibilidade legal apenas no futuro), não podem deixar de ser contempladas. Poderiam estar incluídos nesta última categoria, digamos, o valor atual das indenizações continentes futuras ou provisionamento para 
pensão, no caso de a entidade ter alguma obrigação por tais pagamentos provocam a exigibilidade se configurem às vezes no futuro, de alguma forma o fato gerador esta relacionado a eventos passados ou presentes, não podendo, apenas, prever exatamente quanto e quando senão recorrendo a cálculos provisionais e atuariais".

\section{Contabilização}

O lançamento contábil terá a seguinte e estrutura em cada mês:

Débito : Indenização por Despedida sem Justa Causa (custo de despesa operacional)

Crédito: Provisão para Indenização na despedida

A conta de provisão terá, ao contrario do que poderia ocorrer no $2^{\circ}$ critério, sempre saldo credor, pois a exigibilidade se mantém cumulativamente ao longo dos anos.

Finalmente, um comentário quanto à correta classificação deste item de custo.

Por ter seu valor determinado em função de estimativas, ele pode, em principio, ser tratado como custo indireto.

Todavia, se o valor assim provisionado for efetivamente comprovado na prática, com razoável precisão, passa a poder compor o custo direto, na parte relativa à mão-de-obra direta.

Aspectos Fiscais

No Brasil, o regulamento do Imposto de Renda não admite a dedutibilidade da provisão aqui estudada. Logo, ao final de cada período-base de apuração do Imposto, o saldo da conta de provisão deverá ser oferecido à tributação, através de ajuste ao Lucro Liquido do exercício a ser registrado no Livro de Apuração do Lucro Real *(Deduzido evidentemente, do saldo já tributado no ano anterior).

\section{Problema dos Reajustes e Aumentos Salariais}

As Provisões e as Variações Nominais de Salário

Introdução

A concorrência de elevadas taxas de inflação por longos períodos faz com que os trabalhadores obtenham reajuste salariais com frequiência cada vez maior, seja por força da lei, das negociações sindicais, ou por liberdade dos empregadores.

Assim, os valores das provisões até aqui ficam desatualizados pouco tempo. 
O objetivo desta seção é propor e analisar metodologias de cálculos e tratamentos contábeis adequados a solução do problema do ajuste das provisões aos novos salários nominais, são apenas dos encargos em si, mas também das respectivas contribuições sociais.

Os principais métodos na literatura são:

a) Atualização no mês do reajuste salarial;

b) Antecipação dos reajustes futuros estimados e

c) Correção monetária mensal.

a) Atualização no mês de Reajuste Salarial

Por este método, o saldo as conta provisão é ajustado apenas por ocasião da concorrência da correção salarial.

O valor do ajuste será necessário para complementar a provisão até o limite do direito adquirido pelos empregados, com base no salário atualizado.

A contrapartida da provisão será um débito em conta de custo ou despesa operacional, e irá impactar relevantemente o resultado do mês, quebrando a competência mensal. A anual, porém poderá ser mantida, principalmente no caso do $13^{\circ}$ Salário.

Vejamos o exemplo de Lopez Lopez (Lopez Lopes: José Alberto. Provisão de encargos Sociais sobre a provisão de feriais e de $13^{\circ}$ Salário. Revista Brasileira de Contabilidade (RBC)São Paulo, 50 (1): 48 e 49, 1984)

Um empregado recebe salário mensal de:

$\$ 100.000$ de janeiro a junho

$\$ 140.000$ de junho a setembro

$\$ 160.000$ de outubro a dezembro

As provisões seriam:

De janeiro a junho $\$ 8.333,33$ por mês $(\$ 100.000 / 12)$;

. Em junho \$31.666,67, sendo:

\$ 11.666,67 correspondentes ao próprio mês de julho

$\$ 140.000 / 12$ e os restantes $\$ 20.000$ relativos aos seis meses anteriores.

. Em agosto e em setembro: $\$ 11.666,67$ por mês;

. Em outubro: \$28.333,29, sendo: 
$\$ 13.333,33$ correspondentes ao próprio mês de outubro $(\$ 160.000 / 12)$ e os restantes $\$ 14.999,96$ relativos ao nove meses anteriores (Observa-se que : os meses de julho e outubro são onerados por valores(20.000 e \$14.999,96 respectivamente)que não lhes cometem;

b) a medida que a periodicidade dos reajustes aumenta, o impacto do reajuste diminui. )

.Em novembro e Dezembro: $\$ 13.333,33$ por mês.

Total: $\$ 160.000,00$

Os principais inconvenientes deste método são:

Quebra de principio da competência mensal com ônus indevidos aos meses em que há reajuste salarial, quando representam, efetivamente, acertos do passado, e

- Tratamento contábil inadequado ao debitar o valor do ajuste ao custo de produção ou a despesa do período.

Porém trata-se de um método de simples operacionalizações, sendo aceitável em pequenas empresas, nas quais, sabidamente, os dados e informações gerados pela contabilidade não costumam ser muito utilizados para fins gerenciais.

b) Antecipação de reajustes Futuras Estimados

Por este método estimam-se os percentuais de reajustes salariais previstos para o período, chegando-se a um valor provável para o pagamento do $13^{\circ}$ Salário e Férias. Dependendo do grau de acerto dessas estimativas, os ajustes as contas de provisão poderão ser pequenos.

Martins(Eliseu Martins: Contabilidade de custos, 3. ed., p.) Ilustra este método com o seguinte caso:

"Se por exemplo, a empresa previr uma antecipação de $15 \%$ em maio é um complemento em outubro de $105 \%$ sobre a mesma base anterior, deverá calcular":

JAN $\quad 100$

FEV $\quad 100$

MAR $\quad 100$

ABR $\quad 100$

MAI $\quad 100$

JUN $\quad 115$

JUL 115

AGO 115

SET $\quad 115$

OUT $\quad 125$ 
NOV $\quad 125$

DEZ $\quad 125$

TOTAL $\quad 1.350$

Como o $13^{\circ}$ Salário será de 125 , teremos $125 / 1.350=9,26 \%$ em vez dos $8,33 \%$, se não existisse nenhum aumento $(100 / 12=8,33 \%)$. Deverá, então, provisionar mensalmente o $13^{\circ}$ à base dos $9,26 \%$.

Esse calculo é também válido para a Provisão para Férias. Todavia, deve-se frisar que, para efeito fiscal, não são aceitos provisionamento com base em previsão de aumentos de salários"( $\mathrm{Na} 4^{\circ}$ edição, Eliseu Martins reconhece ser impossível a utilização deste métodos nas taxas de inflação mais recentes.)

Barbieri e Assaf (Barbieri, Geraldo e ASSAF NETO, Alexandre. Estudos dos componentes de encargos sociais da mão de obra no Brasil. Boletim 108 14/83, Temática Contábil e Balanços, p.146-52). Propor e a seguinte equação (adaptada) para se obter a taxa mensal de provisão (reajustes de $40 \%$ em março e $30 \%$ em setembro, cumulativos):

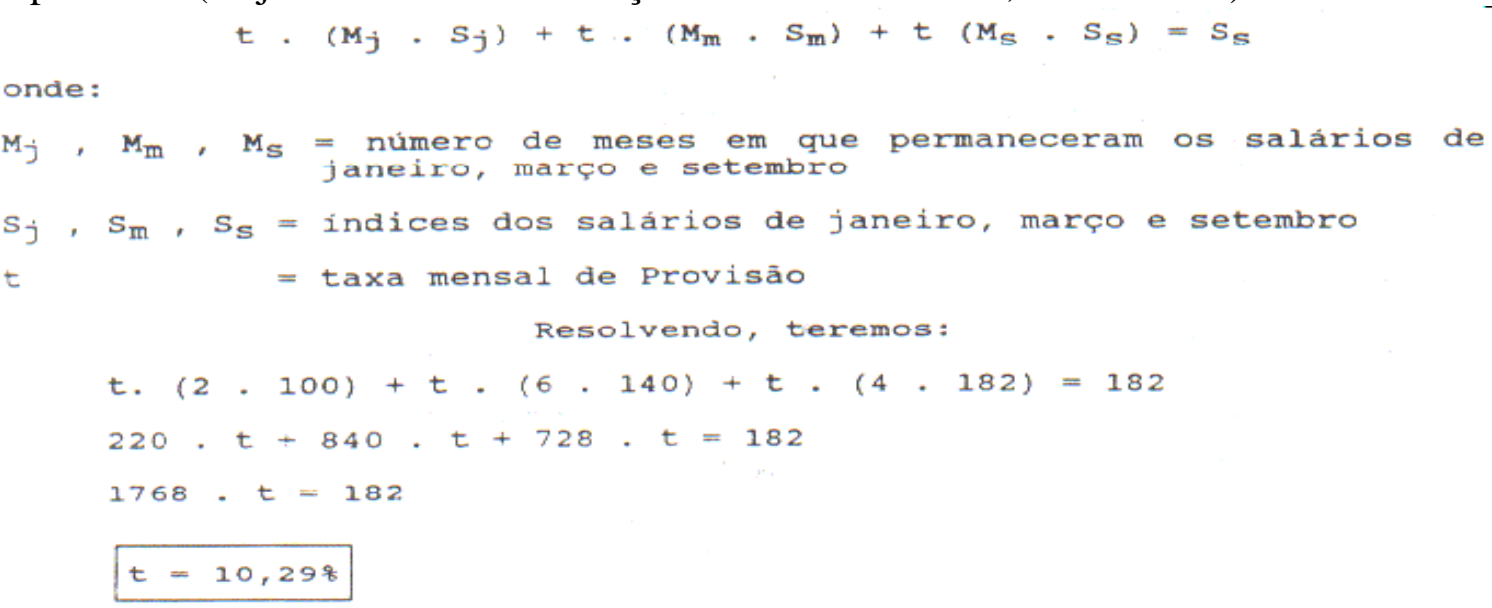

Os autores ressalvam que "essa taxa refere-se ao período de doze meses de trabalho. No entanto, considerando-se que o empregado esta a disposição da empresa somente onze meses no ano, a taxa de provisionamento mensal a ser utilizada nesse caso atinge 11,23\%, ou seja":

$(10,29$. 12) / $11=11,23 ”$

E concluem: “...ressalvando-se, uma vez mais, a limitação imposta pelo físco em não permitir que se estabeleçam provisões baseadas em futuros aumentos salariais".

Resumindo, podemos dizer que este método consiste em:

a) estimar os percentuais de reajustes salariais para o período, e

b) determinar o percentual necessário à constituição das provisões, fazendo:

100. (13º Salário Estimado / salários mensais estimados $)$.

Exemplos: 
Tabela 02: Reajustes Uniformes de $10 \%$ ao Mês

\begin{tabular}{|c|c|c|c|c|c|c|}
\hline \multicolumn{2}{|c|}{ SATÁRIOS } & \multirow{2}{*}{$\frac{\text { DESPESA }}{1.334}$} & 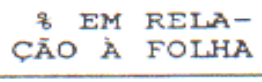 & \multirow{2}{*}{$\begin{array}{l}\text { PROVISÃO } \\
\text { ACUMULADA } \\
1.334\end{array}$} & $\underset{A O}{\Delta}$ ME & \multirow{2}{*}{$\begin{array}{l}\text { REALAÇÃO } \\
\text { ANTERIOR } \\
-\end{array}$} \\
\hline JAN & 10.000 & & 13,34 & & & \\
\hline FEV & 11.000 & 1.468 & 13,34 & 2.802 & & 10 \\
\hline MAR & 12.100 & 1.614 & 13,34 & 4.416 & & 10 \\
\hline ABR & 13.310 & 1.776 & 13,34 & 6.192 & & 10 \\
\hline MAI & 14.641 & 1.953 & 13,34 & 8.145 & & 10 \\
\hline JUN & 16.105 & 2.149 & 13,34 & 10,294 & & 10 \\
\hline JUL & 17.716 & 2.364 & 13,34 & 12.658 & & 10 \\
\hline AGO & 19.487 & 2.600 & 13,34 & 15.258 & & 10 \\
\hline SET & 21.436 & 2.860 & 13,34 & 18.118 & & 10 \\
\hline OUT & 23.579 & 3.145 & 13,34 & 21.264 & & 10 \\
\hline NOV & 25.937 & 3.461 & 13,34 & 24.725 & & 10 \\
\hline \multirow[t]{2}{*}{$D E Z$} & 28.531 & 3.807 & 13,34 & 28.532 & & 10 \\
\hline & 213.842 & 28.532 & - & - & & - \\
\hline
\end{tabular}

Tabela 3: Reajustes em Percentuais Variáveis

\begin{tabular}{|c|c|c|c|c|c|c|c|}
\hline Mês & \& REAJUSTE & SALÁRIOS & DESPESA & $\begin{array}{l}\text { \& EM REL. } \\
\text { A FOLHA }\end{array}$ & $\begin{array}{l}\triangle \text { \&े } \\
\mathrm{AO}\end{array}$ & $\begin{array}{l}\text { REL. } \\
\text { ANT. }\end{array}$ & PROVISÃO \\
\hline JAN & - & 10.000 & 1.723 & 17.23 & - & & 1.723 \\
\hline FEV & 20,00 & 12.000 & 2.068 & 17,23 & 20 & & 3.791 \\
\hline MAR & 16,00 & 13.920 & 2.398 & 17,23 & 16 & & 6.189 \\
\hline ABR & 16,00 & 16.147 & 2.782 & 17,23 & 16 & & 8.971 \\
\hline MAI & 16,00 & 18.731 & 3.227 & 17,23 & 16 & & 12.198 \\
\hline JUN & 18,00 & 22.102 & 3.808 & 17,23 & 18 & & 16.006 \\
\hline TUL & 18,00 & 26.081 & 4.494 & 17.23 & 18 & & 20.500 \\
\hline AGO & 18,00 & 30.775 & 5.303 & 17,23 & 18 & & 25.803 \\
\hline SET & 14,00 & 35.084 & 6.045 & 17,23 & 14 & & 31.848 \\
\hline OUT & 14,00 & 39.995 & 6.891 & 17.23 & 14 & & 38.739 \\
\hline NOV & 25,00 & 49.994 & 8.614 & 17,23 & 25 & & 47.353 \\
\hline DEZ & 15,00 & 57.493 & 9.906 & 17,23 & 15 & & 57.259 \\
\hline TOT & 475,00 & 332.322 & 57.259 & & & & \\
\hline
\end{tabular}

Observa-se que o percentual da provisão sobre o valor dos salários é constante $(13,34$ e $17,23 \%$, respectivamente).

Porém, há um problema: no caso da rescisão de contrato antes do fim do ano, o saldo da conta de provisão estará com valor superior ao devido ao empregado. Se o desligamento ocorrer em junho, por exemplo, o valor a ser pago seria $\$ 8.052,50$ (no primeiro caso) e \$11.051,00 (no segundo). Mas as provisões são de \$10.294 e \$ 16.006,00 respectivamente; daí a necessidade de reverter o excesso. Isto ocorre, evidentemente por estarmos antecipando a apropriação relativa a todos os futuros reajustes, até o fim do ano. Como não se espera que muitos empregados saiam da empresa, as diferenças deverão ser irrelevantes, sendo válido, portanto o método.

Os principais inconvenientes deste método são: 
. dificuldade de se prever reajustes salariais, especialmente em épocas de elevadas taxas de inflação;

. supervivência de provisão em caso de rescisão de contrato no decorrer do ano;

. tratamento contábil inadequado ao debitar o valor dos reajustes ao custo de produção do período.

Principais vantagens:

. operacionalização relativamente fácil;

. distribuição dos encargos de maneira mais homogênea ao longo do ano;

. obediência ao principio da competência;

. manutenção da proporção encargo / salário ao longo de todo o período.

É um método muito mais recomendável do que a da seção anterior.

c) Correção Monetária Mensal

Por este método o saldo da conta de provisão é corrigido mensalmente por índice que reflita a variação do poder aquisitivo método da moeda.

A contrapartida da provisão será um débito em conta da variação Monetária.

Dizem Martins, Iudicibus e Gelbcke (Martins, Eliseu; Iudicibus, Sergio de; Gelbecke, Ernesto Rubens. Manual de Contabilidade das sociedades por ações 3.ed., São Paulo: Atlas1990, p.395.) a respeito do assunto: “ Assim, consideramos que estas provisões devem sofrer correção monetária, a debito de uma conta, por exemplo de Variações Monetárias Provisão para Férias e $13^{\circ}$ Salário. Com isso, só o eventual reajuste salarial real (diferente do índice de correção) entra como encargo de pessoal".

Mas adiante, Afirmam: "Essa atualização deve ser feita mesmo quando o reajuste salarial não é mensal. Só há um problema, nesse caso, pela não dedutibilidade fiscal desta correção sem o reajuste".

Consultando o manual de Normas e Praticas Contábeis no Brasil (FIPECAFI /ATHUR ANDERSEN., São Paulo Atlas, 1990, p.119.) encontramos a página 265: “Todas as provisões devem também estar devidamente atualizadas no balanço, só que em função da variação de preços das obrigações a que se referem”. O “Preço da obrigação", no caso, é o valor do salário do empregado, que será a base do calculo das provisões que irão figurar no balanço de fim de período. Isso não significa que as correções mensais, durante um período

Caderno de Estudos nº, São Paulo, FIPECAFI - Março/1992 
contábil, devam ser efetuadas de acordo com o índice de variação salarial, e sim, como dissemos no início por índice que reflita a variação do poder aquisitivo médio da moeda.

Diz Eliseu Martins (Martins, Eliseu. Contabilidade de Custos. 4.ed., São Paulo, Atlas, 1990, p. 119.)."achamos que as provisões para férias, $13^{\circ}$ Salário e seus encargos sociais devem, em cada mês, sofrer primeiramente, uma correção pelo índice oficial de inflação, tendo como contrapartida uma despesa de variação monetária".

Resumindo, (Martins, Eliseu. Contabilidade de Custos. 4.ed., p.120)diz que este método consiste em atualizar "atualizar mensalmente o saldo anterior da provisão através da taxa de inflação do mês, registrando a contrapartida em conta de variação monetária”. E mais adiante (Martins, Eliseu. Contabilidade de Custos. 4.ed.,p.121.)" a despesa de variação monetária, originada pela atualização do saldo da provisão, é dedutível na apuração do imposto de renda, visto que a legislação permite, até o limite do salário de dezembro”.

Um exemplo completo e bem ilustrativo da aplicação deste método encontra-se as páginas 120 e 121 da $4^{\circ}$ edição do livro Contabilidade de Custos, do Professor Eliseu Martins.

Uma observação importante quanto ao método que estamos estudando a utilização da contabilidade a nível geral de preços irá apurar, nas contas de provisão, ganhos inflacionários nominais que serão anulados pelo saldo devedor da conta de variação monetária.

Permanecerão como ganhos reais, na demonstração do resultado, apenas os relativos a aumentos reais de salários. Ganha-se em transparência e fidedignidade da informação contábil.

As principais vantagens destes métodos são:

. Operacionalização relativamente simples;

. Manutenção da homogeneidade da distribuição dos encargos ao longo do ano;

- Manutenção do princípio da competência e

- Tratamento contábil tecnicamente mais correto, dada a perfeita contabilização com o sistema de correção monetária integral das demonstrações financeiras.

E o método mais recomendável.

1. Variações Reais de Salários

Introdução

As variações reais de salários, em determinado período, podem ser positivas ou negativas, isto é os trabalhadores podem obter ganhos ou perdas salariais frente á inflação.

Admite-se que, numa situação normal, é de se esperar que haja ganhos reais, ao menos na data-base da categoria profissional.

Caderno de Estudos nº, São Paulo, FIPECAFI - Março/1992 
Assim é necessário estabelecer o tratamento contábil que melhor reflita essa variação, no que se refere:

. A apropriação como custo ou despesa operacional

. ao ajuste do saldo da conta de provisão

.a melhor época para realizar esses registros.

As alternativas são:

a) a apropriação de uma só vez, no mês em que ocorrer o aumento,

b) estimativa dos aumentos futuros.

c) A análise de cada uma destas alternativas é exatamente igual as apresentadas na seção anterior, onde tratamos as variações nominais de salários, sendo, portanto, desnecessário repeti-las.

Porém é conveniente enfatizar os aspectos positivos e os negativos de cada método.

Quadro 1: Vantagens e desvantagens de cada método

\begin{tabular}{|c|c|}
\hline $\begin{array}{llll}\text { APROPRIAÇÃO } & \text { NO } & \text { MÊS } & \text { DE } \\
\text { AUMENTO } & & & \end{array}$ & $\begin{array}{lll}\text { ESTIMATIVA } & \text { DOS } & \text { AUMENTOS } \\
\text { FUTUROS } & & \end{array}$ \\
\hline $\begin{array}{l}\text { Vantagem: } \\
\text { Simplicidade e fácil } \\
\text { operacionalização } \\
\text { Desvantagens: } \\
\text { Quebra da competência } \\
\text { Bruscos aumentos de custos no mês } \\
\text { do aumento }\end{array}$ & $\begin{array}{l}\text { Vantagens: } \\
\text {. Simplicidade e fácil } \\
\text { operacionalização } \\
\text {. Distribuição homogênea ao longo do } \\
\text { ano } \\
\text { Obediência ao principio de } \\
\text { competência } \\
\text { Desvantagens: } \\
\text { Dificuldade de se prever aumentos } \\
\text { salariais } \\
\text { Superveniência de provisão em caso de } \\
\text { rescisão de contrato antes do aumento. }\end{array}$ \\
\hline
\end{tabular}


Bibliografia:

ROCHA, Welington. Encargos Sociais no Brasil Antes e Depois da Constituição Federal de 1988. São Paulo: FEA-USP, 1991 (Dissertação de Mestrado).

\section{Correção do Resultado Mensal}

A correção monetária do lucro do próprio exercício é um assunto que já causou muita polêmica e que agora, com a edição da Lei $n^{\circ} 8.383$ de 30.12 .91 , vem à tona novamente.

O capitulo IV da referida Lei versa sobre o Imposto de Renda das Pessoas Jurídicas.

"Artigo 38 - A partir do mês de janeiro de 1992, o imposto de renda das pessoas jurídicas será devido mensalmente, à medida em que os lucro forem auferidos.

Parágrafo $1^{\circ}$ - Para efeito do disposto neste artigo, as pessoas jurídicas deverão apurar, mensalmente a base e o imposto devido

Parágrafo $9^{\circ}$ - Os resultados apurados em cada mês serão corrigidos monetariamente (Lei nº.200 de 1991)".

No artigo 39 da Lei $n^{\circ} 8.383$ encontramos algumas opções para o pagamento do imposto de renda devido, mas o parágrafo $3^{\circ}$ do artigo 39 determina que o imposto apurado nos balanços ou balancetes seja convertido em quantidade de UFIR diária pelo valor desta no último dia do mês a que se referir e, conforme o parágrafo $6^{\circ}$ do mesmo artigo, o imposto devido em cada mês, após as deduções possíveis poderá ser pago até o último dia útil do mês subseqüente, desde que atualizado.

Ainda de acordo com o artigo 39, parágrafos $7^{\circ}$ e $8^{\circ}$, o prejuízo apurado na demonstração do Lucro real dos meses subseqüentes e, para efeito desta compensação, o prejuízo será corrigido monetariamente com base na variação acumulada da UFIR diária.

A fim de esclarecer melhor o assunto vamos trabalhar com um exemplo simples, mostrando também as demonstrações de acordo com a metodologia da Correção Integral (Legislação CVM - Comissão de Valores Mobiliários)

Balanços

\begin{tabular}{|l|c|c|c|c|}
\hline \multicolumn{1}{|c|}{ ATIVO } & $31.12 . \mathrm{XO}$ & $31.01 . \mathrm{X} 1$ & $28.02 . \mathrm{X} 1$ & $31.03 . \mathrm{X} 1$ \\
\hline \multicolumn{1}{|c|}{ Caixa } & 300.000 & 400.000 & 466.077 & 766.007 \\
\hline Total Ativo & 300.000 & 400.000 & 466.077 & 766.077 \\
\hline $\begin{array}{l}\text { Prov. } \\
\text { I.Renda }\end{array}$ & ------------ & 3.000 & ------------- & 28.269 \\
\hline $\begin{array}{l}\text { Cap. } \\
\text { Corrigido }\end{array}$ & 300.000 & 390.000 & 510.000 & 660.000 \\
\hline $\begin{array}{l}\text { Lucro do } \\
\text { Exer. }\end{array}$ & ------------- & 7.000 & 9.154 & (4) 77.808 \\
\hline
\end{tabular}

Caderno de Estudos n4, São Paulo, FIPECAFI - Março/1992 


\begin{tabular}{|l|c|c|c|c|}
\hline $\begin{array}{l}\text { Total. Pás. + } \\
\text { P.L }\end{array}$ & -------------- & 400.000 & 466.077 & 766.077 \\
\hline
\end{tabular}

Demonstrações do Resultado

\begin{tabular}{|l|l|l|c|}
\hline & Janeiro X1 & Fevereiro X1 & Março X1 \\
\hline Receitas & 500.000 & 550.000 & 800.000 \\
\hline Custos dos Serviços & $(400.000)$ & $(480.000)$ & $(500.000)$ \\
\hline Lucro Bruto & 100.000 & 70.000 & 300.000 \\
\hline (3)Desp.Var.Mon.I.Renda & -------- & $(923)$ & -------- \\
\hline (1)Correção Monetária & $90.000)$ & $(112.154)$ & $(137.081)$ \\
\hline L.A .I. R & 10.000 & $(53.077)$ & $(162.919)$ \\
\hline (2)P.I. Renda & $(3.000)$ & $(53.077)$ & 162.919 \\
\hline Lucro Liquido & 7.000 & $(53.077)$ & 134.650 \\
\hline
\end{tabular}

Obs. Todas as Receitas e Custos dos Serviços foram á vista.

\begin{tabular}{|ll|}
\hline UFIR's & \\
\hline 31.12.X0 & $=\$ 100,00$ \\
Médio janeiro & $=\$ 114,00$ \\
31.01.X1 & $=\$ 130,00$ \\
Médio Fevereiro & $=\$ 148,00$ \\
28.02.X1 & $=\$ 170,00$ \\
Médio Março & $=\$ 195,00$ \\
31.03.X1 & $\$ 220,00$ \\
& \\
\hline
\end{tabular}

(1) Janeiro

Capital Corrigido $=\$ 300.000 \times 130,00$

$$
\begin{aligned}
& (------)=\$ 390.000 \\
& 130,00
\end{aligned}
$$

Valor da Correção $=\$ 390.000-\$ 300.000=\$ 90.000$

Fevereiro

Capital Corrigido $=\$ 390.000 \times 170,00$

$$
(------)=\$ 510.000
$$

130,00

Valor da Correção $=\$ 510.000-\$ 390.000=\$ 120.000$

Lucro do Exercício Corrigido $=\$ 7.000 \times 170,00$

$$
\begin{aligned}
& (-----)=\$ 9.154 \\
& 130,00
\end{aligned}
$$

Caderno de Estudos n4, São Paulo, FIPECAFI - Março/1992 
Valor da Correção $=\$ 9.154-\$ 7.000=\$ 2.154$

Correção Monetária de Fevereiro $=\$ 120.000+\$ 2.154=\$ 122.154$

Março

Capital Corrigido $\$ 510.000 \times 220,00$

$$
\begin{gathered}
(-----) \\
170,00
\end{gathered}=\$ 660.000
$$

Valor da Correção $=\$ 660.000-\$ 510.000=\$ 150.000$

Lucro do Exercício Corrigido $=\$ 9.154 \times 220,00$

$$
(-----)=\$ 11.846
$$

170,00

Valor da Correção $=\$ 11.846-\$ 9.154=\$ 2.692$

Prejuízo do mês de Fevereiro $=\$ 53.077$ x 220,00

$$
\begin{aligned}
& (------)=\$ 68.688 \\
& 170,00
\end{aligned}
$$

Valor da Correção $=\$ 68.688-\$ 53.007=15.611$

\section{Correção Monetária de Março}

$\begin{array}{ll}\text { Capital } & =\$ 150.000 \text { (Despesa) } \\ \text { Lucro } & =\$ 2.692 \text { (Despesa) } \\ \text { Prejuízo } & =\$ 15.611 \text { (Receita) } \\ & =\$ 137.081 \text { (Despesa) }\end{array}$

Fizemos a Correção monetária do lucro e do prejuízo separadamente para efeitos didáticos, poderíamos faze-la de uma só vez e chegaríamos ao mesmo numero, ou seja

(\$9.154 - \$53.077) X 077 x 220,00

$$
(------1)=\$ 12.919 r=(\$ 15.611 \mathrm{r}-\mathrm{r}-\$ 2.692 \mathrm{D})
$$

Provisão para Imposto de Renda (supondo-se aliquot de 30\%): 
Janeiro $=\$ 10.000 \times 0,30=\$ 3.000$ foram para em 28.02 corrigidos pela UFIR.

Março $=$ Lucro antes de compensar o prejuízo $=\$ 919$

Prejuízo corrigido $\quad=\$ 688$

Lucro Tributável \$231

Provisão para o imposto de renda

3) Despesas de Variação Monetária do Imposto de Renda em Fevereiro

$$
\begin{aligned}
& \$ 3.000 \times 170,00 \\
& (------1)=\$ 923 \\
& 130,00
\end{aligned}
$$

4)Lucro do exercício acumulado até março:

$$
\begin{array}{lc}
\text { Lucro de Janeiro corrigido até março } & =\$ 11.846 \\
\begin{array}{l}
\text { Prejuízo de fevereiro corrigido até março } \\
\text { Lucro de março }
\end{array} & =(\$ 68.838) \\
& \$ 134.650 \\
& \$ 77.808
\end{array}
$$

Veja que agora o Lucro Acumulado do Exercício não é a simples soma dos resultados de cada um dos meses e sim a soma destes resultados corrigidos para a moeda de 31.03.X1.

Outra dúvida que temos observado é com respeito à compensação do prejuízo de um mês com os lucros dos meses seguintes, a visto que aparentemente será compensado um prejuízo maior, pois esta compensação será feita utilizando o valor do prejuízo corrigido. Isto é ilusão pois, voltando ao exemplo, tem-se:

Edm fevereiro a empresa do exemplo gerou um prejuízo tributável de $\$ 53.077$ que em moeda de 31.03.X1 é $=\$ 53.077$ x $(220: 170)=68.688$, portanto esta sendo compensado um valor maior de 15.611 (68.688 - \$53.077), mas se observarmos a conta correção monetária do mês de março veremos que foram computadas como receitas de correção monetária do prejuízo exatamente esse mesmo valor.

\section{Como fica tudo isso com a correção integral ?}

A comissão de Valores Mobiliários, através das instruções n¹46/91 e 167/91, determina que, a opção da empresa, as companhias abertas poderão, desde que consistentemente ao longo de cada e xercicio, utilizar para registro de suas opções as seguintes alternativas:

a) Variação mensal da UFIR 
b) A UFIR diária para todas as transações ocorridas no período;

c) Variação monetária no período;

d) Critério misto, sendo:

1) A UFIR diária para as transações que envolvam as contas do ativo permanente e patrimônio liquido e, se for o caso, dos demais itens não monetários;

2) Variação média da UFIR para as demais transações, inclusive para registro das quotas de depreciação, amortização e exaustão.

Usaremos para o exemplo a alternativa (d) item (2), visto que não houve alteração nas contas consideradas não monetária (Patrimônio Liquido) a não ser pelos resultados obtidos.

Transformação em UFIR's

\begin{tabular}{|l|l|l|l|}
\hline Receitas & & UFIR (Média) & $\mathrm{N}^{\mathbf{o}}$ de UFIR's \\
\hline Janeiro & 500.000 & $114,00=$ & $4.385,9649$ \\
\hline fevereiro & 550.000 & $148,00=$ & $3.716,2162$ \\
\hline Março & 800.000 & $195,00=$ & $4.102,5641$ \\
\hline Total & $1.850,00$ & & $12.204,7452$ \\
\hline
\end{tabular}

GANHOS/PERDAS NOS ITENS MONETARIOS QUE NÃO GERAM RECEITAS OU DESPESAS FINANCEIRAS

\begin{tabular}{|c|c|c|c|c|c|c|c|}
\hline CAIXA & & JANEIRO & & FEVEREIRO & & HAPCO & TOTAL \\
\hline Saldo do hes fnt. & & 300.000 & & 400.000 & & 466.077 & \\
\hline : UFIR Find Kes Ant. & $: 100$ & $=3.000,0000$ & $: 130$ & $=3.076,9231$ & $: 170$ & $=2.741,6294$ & \\
\hline : UFIR Kedia Mes Atual & $: 114$ & $=\underline{(2.631,5789)}$ & : 118 & $=(2.702,7027)$ & $: 1 \%$ & $=\underline{(2.390,1385)}$ & \\
\hline Perda & & 368,4211 & & 374,2204 & & 351,4909 & $1.094,1324$ \\
\hline Saldo do hes Atual & & 400.000 & & 466.077 & & 766.077 & \\
\hline : UFIR Kedia Kes Atual & $: 114$ & $=3.508,7719$ & $: 148$ & $=3.149,1689$ & $: 195=$ & $=3.928,6000$ & \\
\hline : UFIR Final Kes Atual & $: 130=$ & $=\underline{(3.076,9231)}$ & $: 170=$ & $=(2.741,6294)$ & $: 220$ & $=\underline{(3.482,1682)}$ & \\
\hline Perda & & 431,8488 & & 407,5395 & & 446,4318 & $1.205,8201$ \\
\hline $\begin{array}{l}\text { * Ajuste devido ao } \\
\text { paganento de 1. Renda }\end{array}$ & & & & & & & \\
\hline en 28.02 & & & & 3,4303 & & & 3,4303 \\
\hline Total das Perdas & & 800,2699 & & 785,1902 & & 797,9227 & $2.383,3828$ \\
\hline
\end{tabular}




\section{Calculo da provisão para Imposto de Renda}

A provisão para o imposto de renda é um valor que já esta em moeda de final de mês, portanto basta dividir o valor provisionado pela UFIR dos final do mês, ou seja:

Provisão para imposto de renda de janeiro $=\$ 3.000: 130=23,0769$.

Como as receitas e as despesas foram divididas pela UFIR média, se a empresa quiser também calcular a provisão para imposto de renda pela UFIR média terá que calcular o ganho sobre este valor do seguinte modo:

Provisão do mês dividida pela ufir média do mês 3.000: $114=26,3158$, menos o ganho gerado.

Ganho na Provisão para Imposto de Renda

Saldo do mês anterior: UFIR do final do mês anterior $0: 100=0$

Saldo do mês anterior: UFIR média do mês atual : $\quad 0: 114=0$

Ganho

Saldo do mês atual: UFIR média do mês atual $=3.000: 114=26,3158$

Saldo do mês atual: UFIR do final do Mês atual $=3.000: 130=23,0769$

Ganho

3,2389

Total de ganhos

3,2389

Subtraindo da provisão para imposto de renda os ganhos proporcionados por esta provisão teremos 26,3158 - 3,2389 $=23,0769$, que é exatamente o valor calculado dividido os 3.000 de provisão pela UFIR de $31.01=\$ 130=23,0769$.

Para o m6es de março vamos simplesmente dividir a provisão de março pela UFIR de 31.03 $=\$ 28.269: \$ 220=128,4955$ UFIR's.

Como os $\$ 3.000$ de imposto provisionados em janeiro serão pagos em 28.02, corrigidos, aquele valor gerou uma despesa dês variação monetária de \$923, mas ao utilizarmos a metodologia da correção integral verificamos que esta despesa simplesmente não existe, pois a provisão para o imposto de renda é um passivo monetário e ela irá gerar um ganho sobre os $\$ 3.000$ de valor igual às despesas de variação monetária, uma vez que o imposto de renda foi corrigido pela variação da UFIR , mas a provisão para imposto de renda ficou exposta à mesma inflação, ou seja:

Despesa de Variação Monetária

Caderno de Estudos nơ, São Paulo, FIPECAFI - Março/1992 
Despesa de Variação 923

Saldo Prov. I. Renda mês anterior 3.000

UFIR Final do mês anterior

UFIR média do mês atual

Saldo Prov. I. Renda mês atual

: UFIR médio do mês atual

: UFIR final do mês atual
$: 148=6,2365$

$: 130=23,0769$

$: 148=(20,2703) \quad(2,8066)$

3.923

$: 148=26,5068$

$: 170=(23.0765) \quad(3.4303)$

Despesas de Variação Monetária

Se olharmos o balanço de 28.02. X+1 não encontraremos o saldo de provisão para imposto de renda de $\$ 3.923$, mas é fácil, mas é fácil entender que se o imposto de renda foi pago em 28.02.X-1, este valor foi baixado nesta data portanto gerou ganho até este dia.

Ao considerarmos este ganho, precisamos fazer também um ajuste nas perdas de caixa foi diminuída de $\$ 3.923$ somente no dia 28.02 ; então, até o dia 28.02 devemos calcular a perda adicional no caixa sobre os $\$ 3.923$ e é por este motivo que temos no mês de fevereiro um ajuste das perdas no caixa de 3,4303 UFIR's.

Comparação das Demonstrações de Resultados

Janeiro

\begin{tabular}{|l|c|l|l|}
\hline & \multicolumn{1}{|c|}{ Legal } & Correção Integral & Em Moeda \\
\hline & \multicolumn{1}{|c|}{$\$$} & \multicolumn{1}{c|}{ UFIR's } & De 31.01.X1 \\
\hline Receitas dos & 400.000 & $4.385,9649$ & 570.175 \\
\hline $\begin{array}{l}\text { Custos } \\
\text { Serviços }\end{array}$ & $3.508,7719$ & 456.140 \\
\hline Lucro Bruto & 100.000 & 877,1930 & 114.035 \\
\hline $\begin{array}{l}\text { Correção } \\
\text { Monetária }\end{array}$ & 90.000 & ------------- & ---------- \\
\hline Perdas no Caixa & -------------- & 800,2699 & 104.035 \\
\hline $\begin{array}{l}\text { Lucro Antes do } \\
\text { Imposto Renda }\end{array}$ & 10.000 & 76,9231 & 10.000 \\
\hline $\begin{array}{l}\text { Prov.para imposto } \\
\text { Renda }\end{array}$ & 3.000 & 23,0769 & 3.000 \\
\hline \multicolumn{2}{|l}{53,8462} & 7.000 \\
\hline Lucro Liquido & 7.000 & & \\
\hline
\end{tabular}

Significado da Conta de Correção Monetária 
Correção das Receitas

Correção dos Custos

Perdas no Caixa

$$
\begin{aligned}
570.175-500.000 & =70.175 \mathrm{R} \\
456.140-400.000 & =56.140 \mathrm{D} \\
& =104.035 \mathrm{D}
\end{aligned}
$$

Valor da Correção Monetária

$90.000 \mathrm{D}$

\begin{tabular}{|c|c|c|c|c|c|}
\hline & \multirow{2}{*}{$\begin{array}{l}\text { Legal } \\
\qquad 5\end{array}$} & \multicolumn{2}{|c|}{ Correcao Integral } & \multicolumn{2}{|c|}{$\begin{array}{c}\text { Correcao Integral } \\
\text { Acunulados ate Fevereiro }\end{array}$} \\
\hline & & UFIR's & $\$$ & UFIR's & $\$$ \\
\hline $\begin{array}{l}\text { Receitas } \\
\text { Custos dos Servicos }\end{array}$ & $\begin{array}{l}550.000 \\
(480.000)\end{array}$ & $\begin{array}{c}3.716,2162 \\
(3.243,2432)\end{array}$ & $\begin{array}{l}631.756 \\
(551.351)\end{array}$ & $\begin{array}{c}8.102,1811 \\
(6.752,0151)\end{array}$ & $\begin{array}{l}1,377.371 \\
(1,147.842)\end{array}$ \\
\hline $\begin{array}{l}\text { Lucro Bruto } \\
\text { Iespaesas U. Kon. I.R. } \\
\text { Correcao Konetaria } \\
\text { Perdas no Caixa }\end{array}$ & $\begin{array}{r}70.000 \\
(923) \\
(122.154) \\
-\end{array}$ & $\begin{array}{c}472,9730 \\
- \\
-\end{array}$ & $\frac{80.405}{-}$ & $1.350,1666$ & 229.528 \\
\hline $\begin{array}{l}\text { Lucro Antes do I. Renda } \\
\text { Prov. p/ Imposto Renda }\end{array}$ & $\begin{array}{l}\overline{(53.077)} \\
-\end{array}$ & $\overline{(312,2172)}$ & $\overline{(53.077)}$ & $\begin{array}{r}(225,2935) \\
(23,0769)\end{array}$ & $\begin{array}{r}\overline{(40.000)} \\
(3.923)\end{array}$ \\
\hline Lucro Liquido & $(53.077)$ & $(312,2172)$ & $\stackrel{(53.077)}{=}$ & $(258,3704)$ & $\stackrel{(43.923)}{\underline{\underline{(4)}}}$ \\
\hline
\end{tabular}

Comparando as Demonstrações de Resultados

Fevereiro X1

Significado da conta de Correção Monetária

Correção de Receitas

Correção dos Custos

Perdas do Caixa

Ganho na Prov. I. Renda

Valor da Correção Monetária

$$
\begin{array}{rr}
(631.756-550.000)= & 81.756 \mathrm{R} \\
(551.351-480.000)= & 71.351 \mathrm{D} \\
& 133.482 \mathrm{D} \\
& 923 \mathrm{R}
\end{array}
$$

122.154 D

É de se notar que com a introdução na conta de correção monetária da correção do lucro do próprio exercício, desde que não se corrija outras contas não monetárias e que não se faça ajustes a valor presente, o resultado mensal legal e integral serão sempre os mesmos.

Agora o resultado legal do mês esta correto, o que não acontecia antes, pois não incluído a correção do resultado do exercício na conta de correção monetária, este valor estava errado e provocava um erro no resultado do mês seguinte, pois este continha a correção dos resultados dos meses anteriores. 
Para confirmar o que estamos dizendo, vamos demonstrar que se não fosse incluída na conta de correção monetária de fevereiro a correção monetária de fevereiro a correção monetária do lucro de janeiro, o resultado de fevereiro seria maior.

- saldo da correção monetária de fevereiro seria somente a

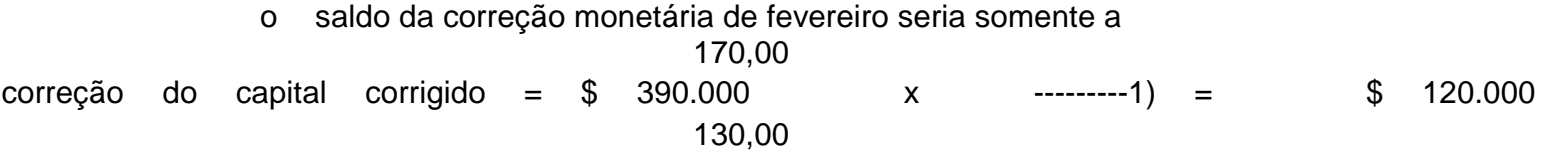

de despesa e o que está sendo considerado na demonstração é \$122.154; se fossem considerados somente os $\$ 120.000$ o resultado de fevereiro seria:
Lucro após despesa financeira $\$ 70.000$ - $\$ 923=$
$\$ 69.077$
Saldo da Correção
$(\$ 120.000)$
Resultado Liquido
$(\$ 50.923)$

e não (\$53.077); portanto seria maior em \$2.154, o resultado de fevereiro estaria aumentado exatamente do valor da correção monetária do lucro de janeiro.

Devemos observar também que os resultados acumulados integral e legal neste exemplo são iguais e somam (\$43.923) e que, para chegar—se a este valor não podemos simplesmente somar os $\$ 7.000$ de lucro de janeiro com os $\$ 53.077$ de prejuízo de fevereiro; o certo é: $\$ 7.000$ corrigidos para moeda de fevereiro $(\$$ $7.000 \times 170: 130 \$ 9.154)$ menos o prejuízo de fevereiro \$53.077, chegando-se aos \$43.923 conforme evidenciado anteriormente no Balanço de 28.02.X1.

\section{Demonstração do Resultado}

\section{Março}

\begin{tabular}{|c|c|c|c|c|c|}
\hline & \multirow{3}{*}{$\begin{array}{c}\text { Legal } \\
\$\end{array}$} & \multicolumn{2}{|c|}{ Correção Integral } & \multicolumn{2}{|c|}{ Correção Integral } \\
\hline & & & & \multicolumn{2}{|c|}{ Acumulado até Março } \\
\hline & & UFIR'S & $\$$ & UFIR's & $\$$ \\
\hline Receitas & 800.000 & 4.102 .5641 & 902.565 & $12.204,7452$ & $2,685.044$ \\
\hline Custos dos Serviços & $(500.000)$ & $(\underline{2.564,1026})$ & $(564.103)$ & $(\underline{9.316,1177)}$ & $(\underline{2,049.546})$ \\
\hline Lucro Bruto & 300.000 & $1.538,4615$ & 338.462 & $2.888,6275$ & 635.498 \\
\hline Correção monetária & $(137.081)$ & -------- & -------- & ---------- & --------- \\
\hline Perdas no Caixa & ------ & $(\underline{797,9227)}$ & $(175.543)$ & $(\underline{2.383,3828})$ & $(524.344)$ \\
\hline Lucro Antes do 1. Renda & 162.919 & 740,5388 & $(162.919)$ & 505,2447 & 111.154 \\
\hline Prov. p/ Imposto Renda & $(28.269)$ & $(\underline{128,4955})$ & $(28.269)$ & $(\underline{151,5724})$ & (33.346) \\
\hline Lucro Liquido & $\underline{134.650}$ & $\underline{612,0433}$ & $\underline{134.650}$ & $\underline{353,6723}$ & 77.808 \\
\hline
\end{tabular}


Significado da Conta de Correção Monetária

Correção das Receitas

Correção dos Custos

Perdas no Caixa

Valor da Correção Monetária
(902.565- 800.000)

(564.103-500.000)

$\begin{array}{ll}=102.565 & R \\ =64.103 & D \\ =175.543 & D\end{array}$

$137.081 \mathrm{D}$

Mais uma vez verificamos que os resultados de março, nos métodos legal e integral, são iguais, confirmando que o resultado legal agora é verdadeiro. Antes da inclusão da correção monetária do resultado do próprio exercício havia sempre uma super avaliação nos resultados mensais. Lembramos mais uma vez que, para chegarmos ao resultado acumulado de $\$ 77.808$, não podemos simplesmente somar os resultados mensais. Devemos corrigi-los para a moeda de março, ou seja:

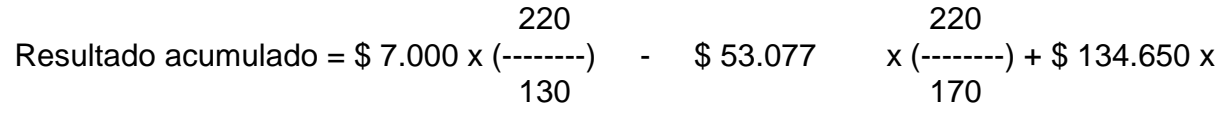

220

$(------)=\$ 77.808$, que é exatamente o valor do lucro acumulado que

220 encontramos no Balanço de 31.03.X+1.

Lembramos também que para chegarmos ao imposto de renda acumulado pelo método da correção monetária legal, temos que atualizar os \$3.000 até março e só depois soma-lo ao imposto de março, ou seja: $\$ 3.000$ X $(220: 130)+\$ 28.269=\$ 33.346$.

Devemos observar ainda que a Lei 8383 de 30/12/91, em seu artigo 43 determina que as pessoas jurídicas embora tenham calculado e pago o imposto de renda com base em balanços ou balancetes mensais, deverão apresentar em cada ano, declaração de ajuste anual, consolidando os resultados mensais. 